\title{
Marko Pilić \\ Europska pravna regulativa suzbijanja terorizma i biosigurnosnih ugroza
}

\begin{abstract}
Sažetak
Borba protiv terorizma i svih njegovih pojavnih oblika globalni je izazov koji zahtijeva stalnu koordinaciju pravnog i praktičnog aspekta međunarodnih i nacionalnih tijela. Relevantan pravni okvir omogućava harmonizirano djelovanje niza aktera protiv tog teškog kaznenog djela. Zato i ne čude stalna nastojanja Europske unije za poboljšanjem pravnog sustava $u$ cilju suzbijanja terorizma. Autor u prvom dijelu rada daje prikaz kaznenopravnog okvira u borbi protiv terorizma, osobito promjena koje su se dogodile u samoj definiciji terorizma te proširenju terorističkih aktivnosti. Drugi dio rada posvećen je aktivnostima Europske unije u suzbijanju jednog specifičnog modaliteta terorizma, bioterorizma, u smjeru smanjivanja pristupa rizičnim i opasnim materijalima, osiguravanja veće spremnosti kao odgovora mogućim biološkim sigurnosnim rizicima, ojačavanja unutarnjih i vanjskih veza s ključnim regionalnim i međunarodnim partnerima Europske unije te povećanja znanja o potencijalnim rizicima. Konačno, autor daje prikaz praktičnih implikacija terorizma na područje Europske unije iz statističkih pokazatelja Europola i CBRN incidenata.
\end{abstract}

Ključne riječi: europska pravna regulativa, suzbijanje terorizma, biosigurnosni rizici, akcijski plan.

\section{Uvod}

Terorizam predstavlja jedan od najtežih oblika kršenja temeljnih ljudskih prava i sloboda, kao i ljudskog dostojanstva i jednakosti. Smatra se da je to napad i na demokraciju te vladavinu prava koja su temelj svim državama članicama Europske unije (dalje u tekstu EU). Terorizam je specifičan oblik agresivnog djelovanja protiv naroda, životne sredine i materijalnih dobara neke zemlje u miru i u ratu. Sama riječ proizlazi iz termina „teror” i pojavljuje se prvi put za vrijeme jakobinske diktature u Francu-

Marko Pilić, mag. forens., Sveučilišni odjel za forenzične znanosti Sveučilišta u Splitu, mpilic@unist.hr 
skoj revoluciji. Teror je vladavina nasilja čiji je cilj zastrašivanje, odnosno uništavanje protivnika. Teror označava akcije nasilja nad nedužnim stanovništvom, pripadnicima policije i vojske te ugrožavanje životne sredine i materijalnih dobara s ciljem zastrašivanja, stvaranja nesigurnosti, dezorganizacije i uništavanja (Cvjetković, 2002: 35). Terorizam predstavlja prijetnju prostoru slobode, sigurnosti i pravde kao temeljnom cilju EU. S obzirom na stalni porast terorističkih prijetnji te njegov prekogranični karakter, na razini EU ali i šire, postoje stalni napori pravne prirode za osiguranje učinkovite borbe protiv terorizma i terorističkih aktivnosti. Premda težnja za borbom protiv terorizma seže vjerojatno od prvih terorističkih aktivnosti s kraja 19. stoljeća (Hoffman, 2006: 10), iz europske perspektive pojam terorizma označavao je zlouporabu moći vladajućih poput režima fašističke Italije, nacističke Njemačke, staljinističke Rusije (Hoffman, 2006: 15-16). U suvremenoj povijesti razvoja terorizma taj se pojam vezuje ponajviše za religiju pri čemu se religija koristi za mobilizaciju novih regruta, povezivanje terorističkih organizacija te opravdavanje terorizma kroz fundamentalističko razumijevanje religije (Bilandžić, 2014: 130-132).

Događaj koji se često obilježava kao svojevrsna prekretnica suvremenog doba koje se otada označuje kao doba terora ili nova era terorizma (Furedi, 2009) teroristički je napad na Sjedinjene Američke Države 11. rujna 2001. Taj je događaj obilježio svjetsku povijest i reflektirao se na Europu tako da već 2003. Vijeće EU usvaja prvu sigurnosnu strategiju kojom se terorizam prikazuje kao rastuća prijetnja cijeloj Europi te ističe njegova povezanost s nasilnim religijskim ekstremizmom. Mogli bismo reći da od tada Europa vodi sustavnu borbu protiv terorizma. Napadi koji su se dogodili na europskom tlu tijekom 2014. i 2015., a kulminirali su napadima u Parizu u noći 13. studenoga 2015., tragično su pokazali da je terorizam prisutan na području Europe i da je stoga potrebno razmjerno pojačati odgovor na razini EU prilagođavajući ga prijetnjama. U svrhu sustavne borbe protiv terorizma i terorističkih aktivnosti na razini EU doneseno je nekoliko pravnih akata kojima je cilj suzbiti terorizam te uspostaviti sveobuhvatan pravni okvir koji će za to biti temelj.

Prvi kaznenopravni odgovor u tom kontekstu predstavlja Okvirna odluka Vijeća 2002/475/PUP od 13. lipnja 2002. o suzbijanju terorizma (dalje u tekstu Okvirna odluka) kao pravni okvir o suzbijanju terorizma. Na temeljnu Okvirnu odluku Vijeća nadogradila se i odluka o pojednostavljenju razmjene informacija i obavještajnih podataka između tijela zaduženih za izvršavanje zakona u državama članicama EU iz 2006. i Odluka Vijeća o produbljivanju prekogranične suradnje, posebno u suzbijanju terorizma i prekograničnog kriminala iz 2008. S obzirom na to da se terorizam ubrzano razvija, a terorističke prijetnje konstantno rastu, recentni pravni izvor na razini EU je Direktiva (EU) 2017/541 Europskog parlamenta i Vijeća od 15. ožujka 2017. o suzbijanju terorizma i zamjeni Okvirne odluke Vijeća 2002/475/PUP i o izmjeni Odluke Vijeća 2005/671/PUP (dalje u tekstu Direktiva). 
Da je terorizam opasna prijetnja, koja samo mijenjajući svoje pojavne oblike ugrožava temeljne vrijednosti, govori i činjenica razvoja bioterorizma kao jednog od oblika terorizma. Bioterorizam se definira kao namjerna uporaba virusa, bakterija, gljivica ili toksina živih organizama koji dovode do smrti ili bolesti ljudi, životinja ili biljaka (Shemer i Shoenfeld, 2007: 27). Stoga je cilj ovoga rada prikazati pregled pravnih izvora o suzbijanju terorizma i bioterorizma na razini Europske unije.

\section{Kaznenopravni okvir}

\section{Prethodna regulativa}

Okvirna odluka predstavlja kamen temeljac kaznenopravnog odgovora država članica u borbi protiv terorizma. Njome se inkriminiraju neka temeljna teroristička kaznena djela poput počinjenja terorističkih napada, sudjelovanje u aktivnostima terorističkih skupina, uključujući financijsku potporu takvim aktivnostima, javno provociranje, novačenje i obuku za terorizam te pravila o pomaganju, sudioništvu, poticanju i pokušaju počinjenja terorističkih kaznenih djela. Međutim, imajući u vidu prekogranični karakter terorizma i stalni porast tzv. stranih terorističkih boraca, vidljivo je da se Okvirnom odlukom ne zahtijeva izričito kriminalizacija putovanja u treće zemlje $s$ terorističkim namjerama niti se izričito zahtijeva kriminalizacija pohađanja obuke u svrhe terorizma. Nadalje, Okvirnom odlukom zahtijeva se samo kriminalizacija financiranja terorizma, što se odnosi na financiranje terorističke skupine, ali ne i na financiranje npr. svih kaznenih djela povezanih s terorističkim aktivnostima, uključujući novačenje, obuku ili putovanje u inozemstvo radi terorizma. To je dovelo do težnje za uspostavom sveobuhvatnijeg pravnog režima u borbi protiv terorizma uključujući tako odgovarajuće odredbe kaznenog prava koje se odnose na fenomen stranih terorističkih boraca i rizike povezane s putovanjem u treće zemlje radi uključivanja u terorističke aktivnosti, ali i povećane prijetnje od počinitelja koji ostaju u Europi. Dakle, diljem EU potrebne su dosljednije, sveobuhvatnije i usklađenije odredbe kaznenog prava kako bi se moglo učinkovito spriječiti i progoniti kaznena djela povezana sa stranim terorističkim borcima te na odgovarajući način odgovoriti na povećane prekogranične praktične i pravne izazove (Prijedlog Direktive, 2015: 3).

Nadalje, u svrhu suzbijanja terorizma na razini Europe donesena je Konvencija Vijeća Europe o sprečavanju terorizma 16. svibnja 2005. u Varšavi s namjerom povećanja napora u suzbijanju terorizma i njegovih negativnih učinaka. Konvencija regulira temeljno terorističko kazneno djelo koje uključuje javno izazivanje na počinjenje terorističkog djela, novačenje za terorizam te obuku za terorizam, kao i sporedna kaznena djela koja uključuju sudioništvo. U svibnju 2015. donesen je dodatni protokol koji dopunjuje Konvenciju tako što zahtijeva inkriminaciju sljedećih djela: sudjelovanje u 
aktivnostima udruge ili skupine u terorističke svrhe, pohađanje obuke za terorističke aktivnosti, putovanje ili pokušaj putovanja radi terorističkih aktivnosti, osiguravanje ili prikupljanje sredstava za takva putovanja i organiziranje i olakšavanje takvih putovanja. EU je 22. listopada 2015. potpisala dodatni protokol i Konvenciju.

$\mathrm{S}$ ciljem što snažnijeg pravnog odgovora na terorizam i aktivnosti usmjerene na terorizam na razini EU, prije donošenja Direktive doneseno je nekoliko pravnih akata koji ukazuju na stalne napore u iznalaženju sveobuhvatnijeg pravnog okvira za borbu protiv terorizma. Tu prije svega treba spomenuti Odluku Vijeća 2005/671/PUP od 20. rujna 2005. o razmjeni informacija i suradnji u vezi s kaznenim djelima terorizma kojoj je cilj učinkovitija suradnja država s Eurojustom i Europolom, kao i osnivanje inačica Eurojusta za područje terorizma u državama članicama. Drugi pravni izvor koji je u nekim državama članicama omogućio konkretan pravni okvir za borbu protiv terorizma, a za države članice koje su ga već imale dodanu vrijednost u jačanju okvira za suradnju s drugim državama članicama pri suočavanju s pripremnim fazama terorističkog djelovanja Okvirna je odluka Vijeća 2008/919/PUP od 28. studenog 2008. o izmjeni Okvirne odluke. Njezina važnost u sveukupnoj borbi protiv terorizma ogleda se u proširenju definicije terorističkih kaznenih djela u odnosu na onu koja je definirana Okvirnom odlukom. Tako terorističke aktivnosti, pored postojećih poput teške krađe, ucjene i izrade lažnih dokumenata radi činjenja terorističkih kaznenih djela, obuhvaćaju javno provociranje radi počinjenja kaznenog djela terorizma, regrutiranje za terorizam te osposobljavanje za terorizam.

\section{Direktiva}

S obzirom na stalni porast terorističkih prijetnji, široki dijapazon radnji koje ulaze u biće terorističkih kaznenih djela, poput putovanja u inozemstvo radi činjenja djela terorizma ili poticanje na terorizam putem interneta, EU se suočio s izazovom koji zahtijeva harmonizaciju definicije terorističkih kaznenih djela u državama članicama. Osim toga, imajući u vidu transnacionalni karakter tih kaznenih djela javlja se potreba prekogranične suradnje država članica i nečlanica EU, osobito u prikupljanju dokaza poput elektroničkih dokaza. Kao rezultat nastojanja pronalaska odgovora na te izazove na razini EU donesen je sveobuhvatni pravni instrument u obliku Direktive (EU) 2017/541 Europskog parlamenta i Vijeća od 15. ožujka 2017. o suzbijanju terorizma i zamjeni Okvirne odluke Vijeća 2002/475/PUP i o izmjeni Odluke Vijeća 2005/671/ PUP (dalje u tekstu Direktiva).

Direktiva je recentni pravni izvor koji taksativno nabraja kaznena djela terorizma (čl. 3. Direktive) kao djela povrede općih vrijednosti ljudskog dostojanstva, slobode, solidarnosti i jednakosti. U tom kontekstu kaznenim djelima terorizma smatraju se napadi na život osobe koji mogu prouzročiti smrt, napadi na fizički integritet osobe, otmica ili uzimanje talaca, nanošenje velikih razaranja vladinom ili javnom objek- 
tu, sustavu prijevoza te infrastrukturnom objektu, uključujući informacijski sustav, fiksnoj platformi smještenoj na epikontinentalnom pojasu te nekom javnom mjestu ili privatnom vlasništvu, koja mogu ugroziti ljudske živote ili dovesti do velikoga gospodarskog gubitka, zatim protupravno oduzimanje zrakoplova, brodova ili drugih sredstava javnog ili teretnog prijevoza, zatim proizvodnja, posjedovanje, stjecanje, prijevoz, nabava ili uporaba eksploziva ili oružja, između ostalog kemijskog, biološkog, radiološkog ili nuklearnog oružja, kao i istraživanje i razvoj kemijskog, biološkog, radiološkog ili nuklearnog oružja, ispuštanje opasnih tvari ili izazivanje požara, poplava ili eksplozija s učinkom ugrožavanja ljudskih života te prijetnja počinjenja bilo kojeg navedenog djela. Osim toga, Direktiva propisuje i kaznena djela povezana s terorističkim aktivnostima, a to su javno poticanje na počinjenje kaznenog djela terorizma, novačenje za terorizam, pružanje obuke za terorizam, pohađanje obuke za terorizam, putovanje u svrhu terorizma, organiziranje ili drukčije olakšavanje putovanja u svrhu terorizma, financiranje terorizma te druga kaznena djela koja su povezana s terorističkim aktivnostima (teška krađa, iznuda, izrada ili uporaba lažnih administrativnih dokumenata s ciljem počinjenja nekog terorističkog kaznenog djela).

Novosti koje donosi Direktiva odnose se na proširenje definicija terorističkih kaznenih djela s obzirom na razvoj modaliteta njihova činjenja. Tako, kad je riječ o putovanju u svrhu činjenja terorističkih kaznenih djela, važnost inkriminacije tih radnji ogledaju se u sve većem porastu prekograničnih terorističkih napada. Međutim, treba naglasiti da ni sama Direktiva ne nalaže obvezu inkriminiranja samog čina putovanja, nego je bitno da se u inozemstvo putuje ili radi činjenja terorističkih kaznenih djela ili radi sudjelovanja $\mathrm{u}$ aktivnostima terorističke skupine. Za implementaciju tih odredaba Direktive u vezi s putovanjem kao činom terorizma treba posegnuti za odredbama koje definira Direktiva (EU) 2016/681 Europskog parlamenta i Vijeća od 27. travnja 2016. o uporabi podataka iz evidencije podataka o putnicima (PNR) u svrhu sprečavanja, otkrivanja, istrage i kaznenog progona kaznenih djela terorizma i teških kaznenih djela. Cilj je te direktive zajamčiti sigurnost, zaštititi živote i sigurnost osoba te uspostaviti pravni okvir za zaštitu podataka iz podataka o putnicima u pogledu njihove obrade koju provode nadležna tijela.

Nadalje, inkriminiranjem pohađanja obuke za terorizam dopunjava se postojeće kazneno djelo pružanja obuke, a koje uključuje stjecanje znanja, pribavljanje dokumentacije ili stjecanje praktičnih vještina. Pritom Direktiva tumači da bi se samostalno učenje, primjerice putem interneta, također trebalo smatrati pohađanjem obuke za terorizam, a koje bi se dokazivalo prema vrsti materijala i učestalosti uporabe. Tako Direktiva navodi da bi se preuzimanje priručnika za izradu eksploziva u svrhu činjenja terorističkih kaznenih djela moglo smatrati pohađanjem obuke za terorizam, dok s druge strane samo posjećivanje internetskih stranica ili prikupljanje materijala u zakonite svrhe, poput akademskih ili istraživačkih, ne smatra se pohađanjem obuke za 
terorizam (točka 11. preambule Direktive). Da bi se postigla učinkovita borba protiv terorizma Direktiva poziva na uklanjanje internetskog sadržaja kojim se javno potiče činjenje terorističkih kaznenih djela, a ako to nije moguće onda blokiranje pristupa takvom sadržaju na području EU.

Kad je riječ o financiranju terorizma, Direktiva navodi kako su određena teška kaznena djela postala unosni načini financiranja terorističkih skupina, poput nezakonite trgovine vatrenim oružjem, naftom, drogama, cigaretama, krivotvorenom robom, trgovine ljudima, reketarenja i ucjene. Stoga je potrebno inkriminirati ne samo financiranje terorističkih djela, nego i financiranje terorističkih skupina te druga kaznena djela povezana s terorističkim aktivnostima.

Novost koju Direktiva donosi jesu i propisane potencijalne olakotne okolnosti koje omogućavaju ublaženje kazne i to pod uvjetima ako počinitelj odustane od terorističkih aktivnosti, pruži pravosudnim tijelima određene informacije koje to tijelo ne bi moglo drugačije pribaviti i to pomažući im da: a) spriječe odnosno ublaže posljedice kaznenog djela, b) privedu ili identificiraju druge počinitelje, c) pribave dokaze i d) spriječe daljnja počinjenja kaznenih djela povezanih s terorističkim aktivnostima.

Imajući u vidu prekogranični karakter terorizma, važnu ulogu u suzbijanju terorističkih aktivnosti ima razmjena informacija tijela kaznenog progona različitih država, i članica i nečlanica EU. Razmjena informacija podrazumijevala bi dostupnost informacija do kojih su došla pravosudna tijela jedne države u drugoj državi u kojoj bi te informacije mogle biti relevantne i takve informacije bi trebale biti relevantne u svim stadijima kaznenog postupka.

Posebnu kategoriju u okviru činjenja terorističkih kaznenih djela imaju žrtve tih djela. Žrtvama terorizma potrebna je zaštita, potpora i pomoć u skladu s njihovim posebnim potrebama. Nakon terorističkih napada ključan je pristup pouzdanim informacijama za žrtve terorizma i o žrtvama terorizma. Budući da su teroristički napadi usmjereni na velike skupine ljudi, žrtve često mogu biti iz drugih zemalja, a ne samo iz zemlje u kojoj se dogodio napad. Prekogranična suradnja između nadležnih nacionalnih tijela stoga je ključna kako bi sve žrtve terorizma bile dobro informirane i primile potrebnu pomoć, neovisno o tome gdje žive u Europskoj uniji. Potpora žrtvama terorističkih kaznenih djela osigurana je i nekim prijašnjim pravnim izvorima. Tako se Direktivom Europskog parlamenta i Vijeća od 25. listopada 2012. o uspostavi minimalnih standarda za prava, potporu i zaštitu žrtava kaznenih djela te o zamjeni Okvirne odluke Vijeća 2001/220/PUP od 15. ožujka 2001. propisuje niz obvezujućih prava za sve žrtve kaznenih djela, uključujući prava na zaštitu, potporu i pomoć kojima se uzimaju u obzir pojedinačne potrebe svake žrtve kaznenog djela. Međutim, tim se odredbama ne predviđaju posebne mjere za žrtve terorizma. Stoga Direktiva dopunjuje već postojeću direktivu u pogledu mjera za zaštitu žrtava terorizma (čl. 24., 25. i 26.). 
Države članice EU Direktivu su trebale implementirati do 8. rujna 2018. U svrhu implementacije odredaba iz Direktive, hrvatski je Kazneni zakon novelom iz 2018. uveo neke nove inkriminacije u vezi s terorističkim kaznenim djelima. Osim određenih korekcija postojećih inkriminacija u koje spadaju terorizam (čl. 97.), financiranje terorizma (čl. 98.), javno poticanje na terorizam (čl. 99.), novačenje za terorizam (čl. 100.), obuka za terorizam (čl. 101.)., u svrhu implementacije Direktive uvedeno je novo kazneno djelo putovanje u svrhu terorizma (čl. 101.a). Treba također naglasiti da kazneni progon za kazneno djelo terorizma ne zastarijeva, što ukazuje na težinu terorističkih kaznenih djela.

\section{Europski pravni okvir u borbi protiv bioterorizma}

Europa je poduzela značajne korake u borbi protiv terorizma, posebice s pravnog aspekta. S obzirom na to da je naglasak stavljen na suradnju država članica, pomno se prate godišnja izvješća Europola o situaciji i trendovima u području terorizma. Od 2001. aktivan je i popis terorista čime je poboljšana zaštita država i granica. Strategijom EU za borbu protiv terorizma, a u smislu stvaranja sigurnije Europe, 2007. je imenovan i koordinator za borbu protiv terorizma. Važno je naglasiti i pravni okvir borbe protiv pranja novca i financiranja terorizma iz 2015. i dodatnu izmjenu postojećih pravila iz 2016. (Primorac, Miletić i Pilić, 2018: 69). Godine 2016. uveden je registar putnika, odnosno upotreba podataka iz evidencije o putnicima u EU. Treba istaknuti i protuterorističku strategiju, zaštitu kritičnih infrastruktura, europsku sudsku mrežu, europski vizni informacijski sustav, razmjenu informacija o terorističkim otmicama, pravila Vijeća o sigurnosti i zaštiti povjerljivih informacija i drugo (Vijeće Europske unije, 2020).

\section{Akcijski plan za povećanje spremnosti protiv CBRN ugroza}

Činjenica je da se EU susreće s širokim rasponom terorističkih prijetnji i napada nasilne prirode, bilo specifičnih umreženih grupa ili radikaliziranih pojedinaca kojima je u cilju maksimalan broj žrtava te ekonomski i psihološki udar na društvo (Europol, 2017: 16). Terorističke organizacije još uvijek nisu izvršile napad koristeći kemijsko, biološko, radiološko ili nuklearno oružje (dalje u tekstu CBRN) na području Europe, ali su ga koristile na područjima Sirije i Iraka što dovoljno govori o njihovom interesu za razvoj i implementaciju takve vrste oružja (Interpol, 2017: 3). Važno je naglasiti da će takve organizacije puno prije koristiti kemijsko, biološko ili radiološko oružje nego nuklearno. Sukladno tome, Europska je komisija pokrenula komunikaciju za provođenje akcijskog plana kojemu je cilj povećati spremnost protiv CBRN ugroza. Europska je komisija u komunikaciji prema Europskom parlamentu, Europskom vijeću, Europskom gospodarskom i socijalnom odboru te Europskom odboru regija izdala akcijski 
plan za poboljšanje spremnosti s obzirom na rizike za kemijsku, biološku, radiološku i nuklearnu sigurnost (European Commission, 2017: 4) prema kojem su identificirana četiri primarna cilja: a) smanjivanje pristupa CBRN materijalima, b) osiguravanje veće spremnosti na možebitne CBRN ugroze, c) ojačavanje unutarnjih i vanjskih veza s relevantnim regionalnim i međunarodnim partnerima i d) povećanje znanja o CBRN rizicima.

Europska je komisija u tom pogledu odredila prioritetne akcije koje se moraju odrađivati u bliskoj suradnji između država članica.

\section{Smanjivanje pristupa CBRN materijalima}

U cilju da se smanje možebitne ugroze po društvo upotrebom CBRN materijala, nužno je smanjiti pristup terorista prema agensima i/ili tvarima koje su potrebne za izradu takve vrste oružja. Takav pristup uključuje kontrolu visokorizičnih materijala, odnosno otkrivanje moguće upotrebe u prvoj fazi razvoja takvog oružja. To iziskuje kvalitetniju suradnju, komunikaciju i razmjenu informacija država članica međusobno, kao i država članica s trećim zemljama. Svakako, potrebno je predložiti efikasniju razmjenu informacija koja bi se ponajviše oslanjala na upozorenja sustava umjetne inteligencije. Unaprijed određeni ulazni podaci, dogovoreni na razini EU i ostatka svijeta, implementirali bi se u moderne sustave koji bi upozoravali u tom trenutku sve relevantne institucije i tako potencijalno spriječili samu izradu CBRN oružja. Svakako treba naglasiti i prednost strojnog učenja, kao i dubokog učenja koji bi, zbog „treniranja sustava umjetne inteligencije” mogli predvidjeti buduće prijetnje i prije nego određeni pojedinac i/ili organizacija počne pribavljati potrebne materijale. Upotrebom sustava umjetne inteligencije na taj način omogućilo bi pokretanje istražnih/predistražnih radnji organa unutarnjih poslova u ugroženim državama i potencijalno spriječilo teroristički čin. Razmjena informacija u nabavi visokorizičnih materijala i njihove količine opisana je u slici 1. Počevši od kupnje specifičnih materijala kao polaznim elementom, kreiranje unificirane baze podataka trgovaca i proizvoda koji se izdaju, poboljšala bi se kontrola nadležnih institucija kada je u pitanju izrada naprava/agenasa za terorističke akte. U tom kontekstu, jedinstvena baza i razmjena informacija na razini EU ubrzala bi djelovanje nadležnih tijela i otkrivanje potencijalnih počinitelja tog kaznenog djela.

Uz spomenutu veću upotrebu postojećih alata i sustava za razmjenu informacija, smanjivanju pristupa CBRN materijalima pridonijele bi i sljedeće četiri strateške točke: a) optimizacija razmjene informacija o CBRN opasnostima, b) ojačavanje carinske kontrole na rizičnim područjima, c) povećanje kontrole izvoza na razini EU i d) identifikacija unutarnjih prijetnji. 


\section{Slika 1. Razmjena informacija u nabavi visokorizičnih materijala}

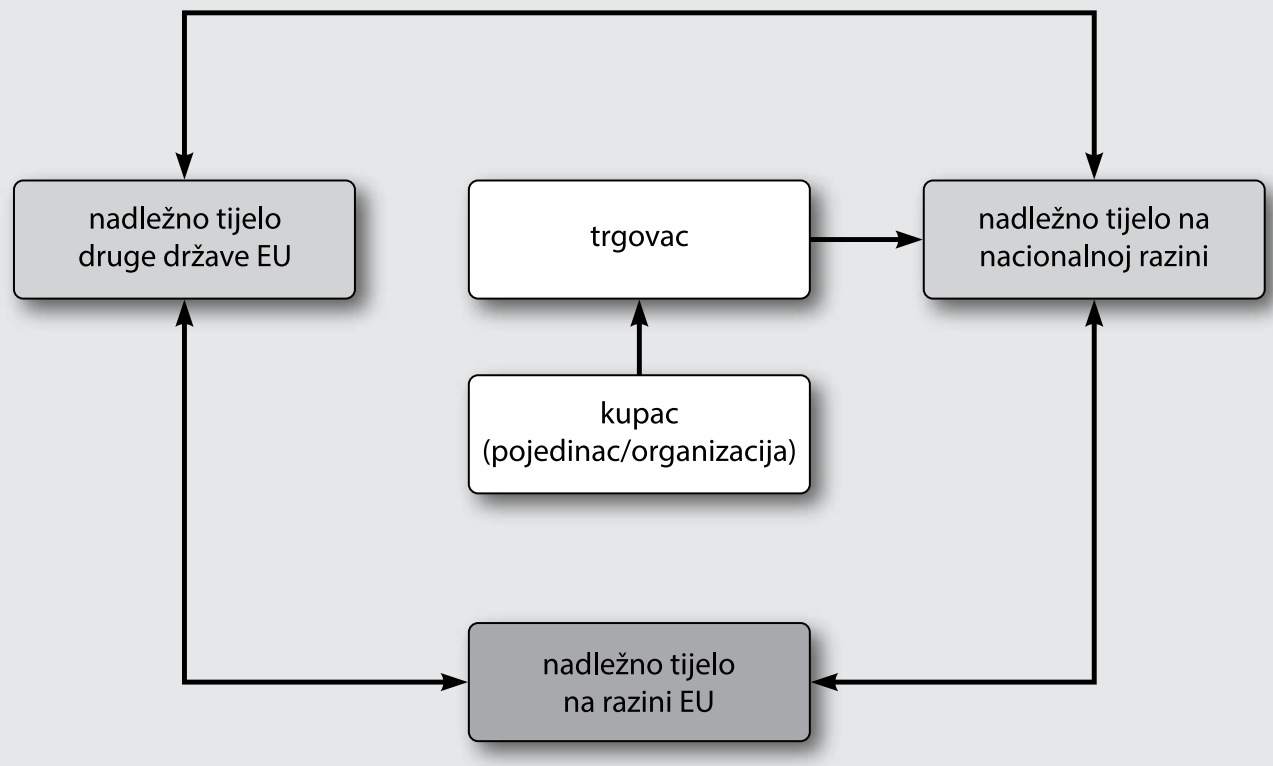

Izvor: autor.

Kada je riječ o optimizaciji razmjene informacija važno je naglasiti da Europol kontrolira Europski sustav podataka o bombama (engl. European Bomb Data System, dalje u tekstu EBDS) odnosno sustav koji je ključan segment razmjene informacija o prošlim i potencijalnim bombaškim napadima te je filter protoka informacija unutar samog sustava, što čini takav sustav iznimno važnim u području preveniranja. Također, važan je napredak u polju slanja i dijeljenja informacija kroz sustav baza podataka o nesrećama i trgovanju (engl. Incident and Trafficking Database, dalje u tekstu ITD) pri Međunarodnoj agenciji za atomsku energiju (dalje u tekstu IAEA) te elektronički sustav za robu s dvojnom namjenom (engl. Dual-Use Electronic System, dalje u tekstu DUeS). Povezanost takvih sustava međusobno je iznimno korisna, pogotovo kada je riječ o dijeljenju informacija o osobama koje se sumnjiči za razmjenu ili trgovanje opasnim tvarima. Upravo je to glavna značajka DUeS sustava, a poboljšanja u tim aspektima razmjene i optimizacije razmjene podataka su nužna. Ojačavanje carinske kontrole na rizičnim područjima pretpostavlja poboljšanje u poljima obujma informacija o dolazećim i odlazećim teretima te povećanje detekcijskih mogućnosti na carinama, kao i suradnja s ostalim agencijama i državnim tijelima u svrhu praćenja međunarodnog lanca dobavljača opasnih tvari kako bi se prepoznao i kontrolirao uvoz i izvoz 
CBRN materijala. Sukladno akcijskom planu preporučuje se proširivanje i pojačavanje obuke za sve policijske i carinske snage koje će biti odgovorne na tim područjima i to $\mathrm{u}$ europskim trening postrojenjima za nuklearnu sigurnost (engl. European Nuclear Security Training Center, dalje u tekstu EUSECTRA). Povećanje EU kontrole izvoza važno je u prevenciji vanjskog djelovanja, bilo države članice ili ne, u pristupu CBRN materijalima kroz njihovo trgovanje te je nužno osvježiti i nadopuniti listu visoko rizičnih CBRN materijala u nadolazećoj godini. Također, identifikacija potencijalnih unutarnjih prijetnji ključna je u borbi protiv bioloških opasnosti. Prema akcijskom planu preporuka je da države članice razmjenjuju informacije i praksu za ograničavanje pristupa prostorima u kojima se skladišti i čuva CBRN materijal i iziskuje se dvostruka provjera osoba kako neželjeni pojedinci ne bi imali pristup takvim postrojenjima. Razmjena već postojećih praksi trebala se početi primjenjivati od početka 2018.

\section{Osiguranje veće spremnosti kao odgovor mogućim CBRN prijetnjama}

Kako bi se osigurala veća spremnost za možebitne CBRN ugroze ključna je operativna spremnost. S obzirom na to da terorizam ne poznaje granice, nužno je ustanoviti kvalitetnu suradnju s prekograničnim i transnacionalnim predznakom. Samim time, spremnost na biosigurnosne rizike može se vrednovati i raznim međusektorskim akcijama i treninzima, jačanjem mehanizama za civilnu zaštitu, provođenjem analize o detekciji mogućih CBRN materijala, poboljšanjem sustava ranog upozorenja kao i izmjenom informacija o ozbiljnim prekograničnim prijetnjama zdravlju. Spremnost na biosigurnosne rizike zahtijeva snažniju tehničku i edukativnu spremnost laboratorija u svrhu identifikacije i brzog dijeljenja uzoraka te podizanje svijesti o spremnosti te protumjere u bioopasnosti. U tom kontekstu, Europska komisija već je organizirala brojne tečajeve izobrazbe i vježbe na razini EU s naglaskom na međusektorskoj suradnji u slučaju CBRN napada.

Kao pozitivan primjer takve prakse može se izdvojiti vježba tzv. Arete iz 2014. kojoj je svrha bila naglasiti važnost suradnje zakonodavnih tijela i civilne zaštite pojedine države u kontekstu kemijske i terorističke ugroze. Uz to, proveden je i niz tečaja iz područja međusektorskog djelovanja na napad radiološkom tzv. prljavom bombom, a kao temelj poslužile su netom prije definirane odredbe iz čl. 2. Odluke 1082/2013/EU o ozbiljnim prekograničnim prijetnjama zdravlju, prema kojima takve prijetnje zdravlju podrazumijevaju: a) biološke prijetnje (zarazne bolesti, antimikrobna otpornost i infekcije vezane uz zdravstvenu skrb i povezane sa zaraznim bolestima, biotoksini ili drugi štetni biološki uzročnici koji nisu povezani sa zaraznim bolestima, b) prijetnje kemijskog podrijetla, c) prijetnje ekološkog podrijetla, d) prijetnje nepoznatog podrijetla i e) događaji koji mogu predstavljati hitne slučajeve međunarodne važnosti koji se odnose na javno zdravlje prema Međunarodnim zdravstvenim propisima, ako ulaze u jednu od kategorija prijetnji navedenih u točkama od (a) do (d). 
Također, potpuna uporaba europskog nuklearno-sigurnosnog trening centra u svrhu osnaživanja sigurnosnih mehanizama za potencijalne nuklearne prijetnje te povećanje suradnje između država članica na području nuklearne forenzike navedeni su kao koraci koji se trebaju poduzeti kako bi se smanjili sigurnosni rizici. Akcijskim planom smatra se da dodatne mjere, poput poboljšanja multiagencijske suradnje, a posebno osoba i službi koje dođu prve na mjesto događaja trebaju biti jasnije definirane što je nadasve slučaj u potencijalnim slučajevima značajnijeg CBRN terorističkog čina.

\section{Ojačavanje unutarnjih $i$ vanjskih veza s ključnim regionalnim i međunarod- nim europskim partnerima}

Kreiranje snažne suradnje među članicama EU u području sigurnosti temelj je strategije u suzbijanju terorizma i održavanju sigurnosnog ozračja. Zbog činjenice da CBRN ugroze mogu nastati i izvan i unutar EU takav pristup poziva na ujedinjenost pri definiranju sigurnosnih politika EU (European Union External Action, 2016: 18). Iako se glavni fokus sigurnosne politike EU odnosi na unutarnju suradnju, veliku važnost predstavlja i odnos s trećim državama, posebice onima u okruženju što ponajviše stavlja naglasak na vanjske granice EU. U tom kontekstu i Republika Hrvatska treba pronaći model kako bi se profilirala kao ključni igrač u održavanju vanjskih granica EU sigurnima. Samim time kao ključ ojačavanja unutarnjih i vanjskih veza s ključnim regionalnim i međunarodnim EU partnerima naglasak je na suradnji, komunikaciji i dijeljenju informacija, prvenstveno između država članica, zatim razvojem posebnog partnerstva s NATO-om i ostalim specijaliziranim međunarodnim organizacijama u vezi s biosigurnosti i biosigurnosnim rizicima. Suradnja s NATO-om preporučuje se i u kontekstu veza s trećim državama, a ponajviše u području razmjene informacija, izgradnje kapaciteta, obrazovanja i vježbi. Akcijskim planom preporučuje se sudjelovanje u raznim međunarodnim organizacijama poput Europske službe za vanjsko djelovanje (engl. European Union External Action Service, dalje u tekstu EEAS), kao i komisije koje će sudjelovati u specijaliziranim multilateralnim organizacijama sastavljene od Interpola, IAEA-e, Organizacije za zabranu kemijskog oružja (engl. Organisation for the prohibition of Chemical Weapons, dalje u tekstu OPCW), Konvencije za biološko oružje (engl. Biological Weapon Convention Implementation Support Unit, dalje u tekstu BWC ISU) i Ured Ujedinjenih naroda za razoružanje (engl. United Nations Office for Disarmament Affairs, UNODA) kako bi se najbolja praksa dijelila međusobno.

\section{Povećanje znanja o CBRN rizicima}

S obzirom na kompleksnost područja sigurnosti i njegovu širinu koja obuhvaća i polje CBRN ugroza, produbljivanje znanja o tome pretpostavlja ključ uspjeha u borbi protiv takvih ugroza. Stručno znanje na razini EU neravnomjerno je raspodijeljeno iako je 
trenutačna situacija s pandemijom SARS-CoV-2 izgradila i ojačala partnerstva i znanja na području EU, ali i svijeta. Uzimajući pandemiju kao primjer važnosti znanja o specifičnim ugrozama poput te biološke, može se zaključiti da je sustav usprkos svim suradnjama i uputama relevantnih svjetskih organizacija ranjiv u slučajevima kada se malo ili ništa ne zna o ugrozama. Imajući to na umu, povezivanje svih relevantnih subjekata, poput država, institucija, agencija i privatnog sektora, od ključne je važnosti za sigurnost EU. Uspostava mreže za sigurnost za područje CBRN ugroza jedan je od važnijih koraka koje su se predložile akcijskim planom. Ta mreža temelji se na trima ključnim elementima: a) centar znanja unutar Europskog centra za borbu protiv terorizma, b) mreža potpore postojećim centrima za CBRN unutar EU i c) savjetodavna skupina s predstavnicima svih država EU kao koordinatorima.

U procesu stjecanja i promicanja stečenih znanja, Europska komisija u svom akcijskom planu predviđa i daljnje reproduciranje znanja dobivenih iz određenih istraživanja, ali i metodama i tehnikama koje su korištene u istraživanjima. Prioriteti istraživanja odnose se na pronalazak rješenja o načinima reduciranja CBRN ugroza koje su u nastajanju poput bespilotnih letjelica i biohakiranja te povećanje prostornih i ostalih kapaciteta država članica kako bi bili spremni na izazove u procesu smanjenja rizika od katastrofa.

\section{Praktične implikacije terorizma na području EU}

\section{Izvješće Europola o situaciji i trendu terorizma 2020.}

U ovome dijelu rada prikazat će se statistički pokazatelji kretanja terorizma i terorističkih aktivnosti na području EU analizirajući Izvješće Europola o situaciji i trendu terorizma za 2020. Primarno, u tome se izvješću teroristička kaznena djela dijele prema skupinama njihova počinjenja. Tako se razlikuju etnonacionalističke i separatističke terorističke skupine kao skupine motivirane nacionalizmom, etničkom pripadnošću i/ili religijom. Separatističke skupine žele sebi stvoriti državu iz veće zemlje ili pripojiti teritorij jedne zemlje drugoj. Irska republikanska vojska (IRA), baskijski ETA i kurdske organizacije PKK spadaju u tu kategoriju (Europol, 2020: 54). Nadalje, tu su lijeve terorističke skupine koje nastoje nasilnim putem pokrenuti revoluciju protiv političkog, socijalnog i ekonomskog sustava države, kako bi uvele socijalizam i na kraju uspostavile komunističko i besklasno društvo. Njihova je ideologija često marksističko-lenjinistička. Primjeri lijevih terorističkih skupina su talijanske Brigate Rosse (Crvene brigade) i grčka revolucionarna organizacija 17. studenog. Anarhistički terorizam krovni je pojam koji se koristi za opisivanje nasilnih djela koja su počinile skupine (ili u manjoj mjeri pojedinci) povezane s različitim anarhističkim ideologijama. Oni promiču revolucionarnu, antikapitalističku i antiautoritarnu agendu. Primje- 
ri anarhističkih terorističkih skupina su talijanska Federazione Anarchica Informale (Neformalna anarhistička federacija) ili grčka Synomosia Pyrinon tis Fotias (Zavjera ćelijskih vatri) (Europol, 2020: 58). Desni terorizam odnosi se na upotrebu terorističkog nasilja desnih ekstremista. Varijante desničarskog ekstremizma su neonacizam, neofašizam i ultranacionalističke formacije. Desni terorizam nastoji promijeniti cjelokupni politički, socijalni i ekonomski sustav na ekstremističkom modelu desnice. Temeljni koncept desničarskog ekstremizma je supremacizam ili ideja da je određena skupina ljudi koja dijeli zajednički element (nacija, rasa, kultura itd.) superiornija od svih ostalih ljudi. Ugledavši sebe na vrhovnom položaju, određena skupina smatra da je njihovo prirodno pravo dominirati ostatkom stanovništva. Uz to, desničarske ekstremističke ideologije hrane se raznim mrskim potkulturama, često se boreći protiv različitosti u društvu i jednakih prava manjina. Rasističko ponašanje, autoritarnost, ksenofobija, mizoginija i neprijateljstvo prema lezbijskim, homoseksualnim, biseksualnim, transrodnim i queer (LGBTQ) zajednicama i imigraciji često su stavovi desničarskih ekstremista (Europol, 2020: 65). Tu treba spomenuti još i ekstremističke i terorističke skupine s jednim problemom koje se koriste kriminalnim sredstvima za promjenu određene politike ili prakse, za razliku od zamjene cjelokupnog političkog, socijalnog i ekonomskog sustava u društvu. Skupine u toj kategoriji bave se naprimjer pravima životinja, zaštitom okoliša ili kampanjom protiv pobačaja. Primjeri skupina u toj kategoriji su Front za oslobađanje zemlje (ELF) i Front za oslobađanje životinja (ALF) (Europol, 2020: 80).

Kad je riječ o statističkim pokazateljima, iz Izvješća je vidljivo da se ukupan broj dovršenih, neuspjelih i onemogućenih terorističkih napada nastavio smanjivati $u$ 2019. u odnosu na prethodnu godinu, uglavnom zbog nastavka pada broja etnonacionalističkih i separatističkih terorističkih napada. Tijekom 2019. tri države članice EU prijavile su ukupno šest desničarskih terorističkih napada (jedan dovršen, jedan neuspješan, četiri onemogućena), u usporedbi sa samo jednim 2018. Pored toga, Njemačka je prijavila dva napada u kojem je život izgubilo troje ljudi, koji nisu klasificirana kao terorizam prema nacionalnom zakonu, ali su ih počinili desničarski ekstremisti. Također, u 2019. desničarski napadi na Christchurch (Novi Zeland), Poway (SAD), El Paso (SAD), Bærum (Norveška) i Halle (Njemačka) bili su dio vala nasilnih incidenata širom svijeta, čiji su počinitelji bili dio sličnih transnacionalnih internetskih zajednica i nadahnjivali se jedni drugima. Osim toga, broj ljevičarskih i anarhističkih terorističkih napada u 2019. (26) dosegnuo je razinu iz 2016. i 2017. nakon pada u 2018. Svi napadi dogodili su se u Grčkoj, Italiji ili Španjolskoj.

U 2019. godini uhićene su 1004 osobe zbog sumnje da su počinile kaznena djela povezana s terorizmom u 19 država članica EU, a najveći broj zabilježile su Belgija, Francuska, Italija, Španjolska i Velika Britanija. Ukupni broj uhićenja lagano se smanjio, ali brojke pokazuju da je terorizam i dalje zemljopisno raširen u EU. 
Slika 2. Izvješće Europola o situaciji i trendu terorizma za 2020.

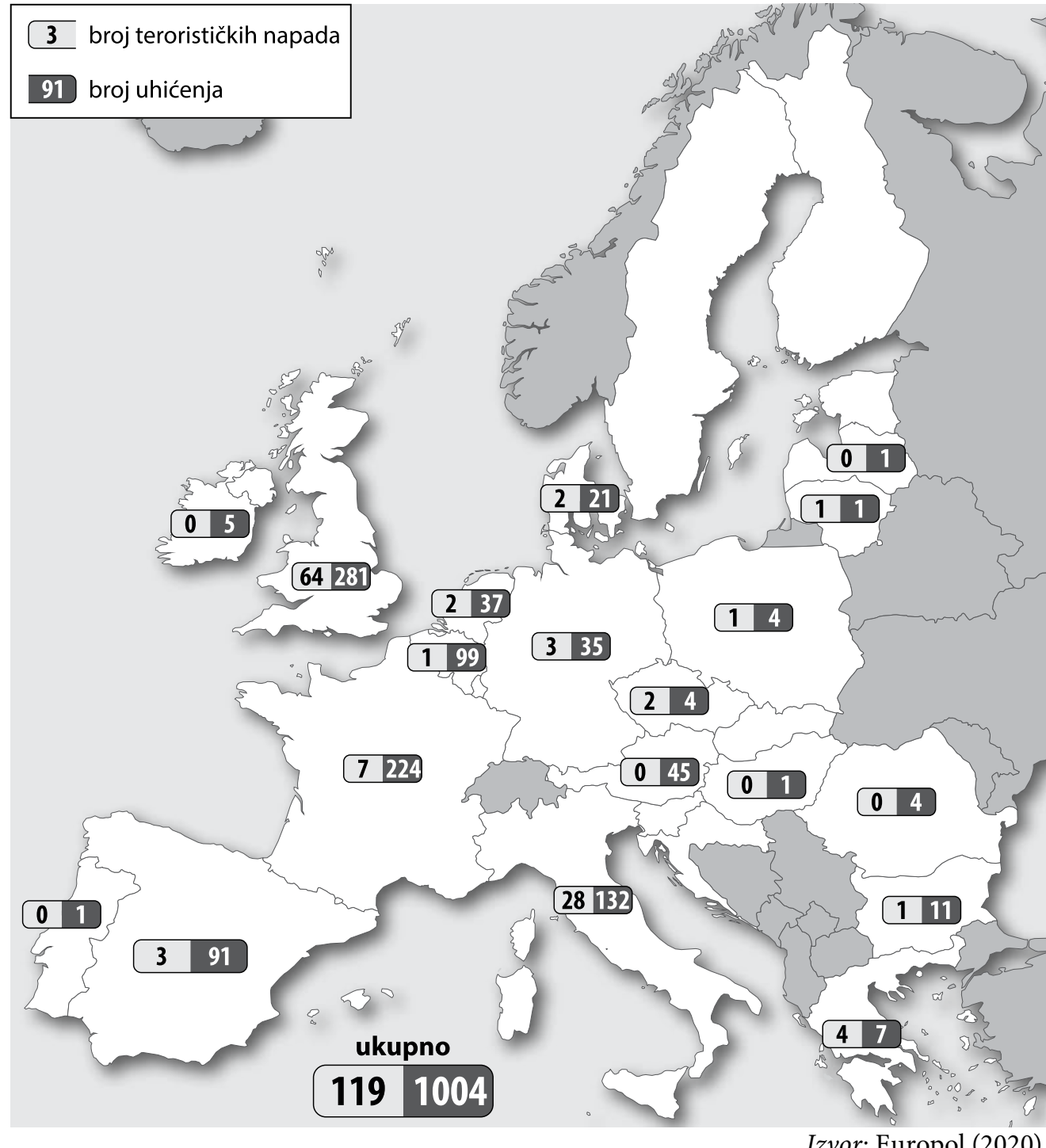

Izvor: Europol (2020).

\section{CBRN incidenti}

Kada je riječ o značajnim CBRN incidentima diljem svijeta, treba istaknuti slučajeve iz Sjedinjenih Američkih Država, Velike Britanije, Francuske, Njemačke, Rusije i Japana. Naglasak je na riječi „incidenti” s obzirom na to da neki od slučajeva nisu smatra- 
ni terorističkim činom zbog same definicije terorizma i neispunjavanja tih odredbi. Primjerice, 2018. najmanje dva pisma poslana su Pentagonu i još jedno Bijeloj kući u kojem se nalazio ricin. Pisma nikada nisu stigla do predviđenih primatelja i presretnuta su mnogo prije nego što su mogla predstavljati opasnost za visoke dužnosnike. Stanovnik savezne države Utah poslije je optužen za slanje pisama, a njegova je optužnica istaknula da je za proizvodnju toksina kupio 380 ricinusovih zrna. Prema američkom zakonu mogao bi se suočiti sa zatvorom zbog prijetnje da će kao oružje upotrijebiti biološki toksin (United States Department of Justice, 2018).

Nervni agens Novichok korišten je 2018. u Salisburyju u sklopu pokušaja atentata na prognanog ruskog špijuna. Napad na bivšeg ruskog vojnog obavještajca Sergeya Skripala i njegovu kćer Juliju izvršen je upotrebom moćnog nervno agensa Novichok kojeg je 1980-ih razvio Sovjetski Savez, prema britanskoj vladi i neovisnim analitičarima. Velika Britanija još se uvijek mora suočiti s prijetnjom nedržavnih terorističkih skupina i potencijalnim CBRN napadom. Osoba iz Liverpoola osuđena je 2015. na osam godina zatvora zbog pokušaja kupnje ricina preko interneta, odnosno Dark weba (The Guardian, 2018).

Francuske sigurnosne službe osujetile su potencijalni napad ricinom na njezino tlo u 2018. Student koji je rođen u Egiptu uhićen je i optužen nakon što su policajci presreli poruke na platformi društvenih mreža Telegram i kasnije pronašli materijale s uputama za proizvodnju ricina (koji je možda bio isti kao i materijal korišten u kölnskoj ricinskoj zavjeri - vidi niže Njemačka). Nejasno je koliko je zavjera bila napredna, iako se ne vjeruje da je osumnjičeni uspio stvoriti bilo kakav ricin. Nema dodatnih podataka o suđenju osumnjičenom (France, 2018).

Njemačke snage sigurnosti onemogućile su 2018. smrtonosnu zavjeru o ricinu koju su planirali Tunižanin i njegova supruga Nijemica u gradu Kölnu. Njemački savezni tužitelji tvrdili su da je par bio radikaliziran i ,identificiran s ciljevima i vrijednostima strane terorističke organizacije Islamska država." Čovjek je imao veze s islamskim ekstremistima i dvaput je pokušao putovati u Siriju, kao i pomoći Islamskoj državi u njihovom propagandnom radu. Par je planirao napraviti eksplozivnu napravu koja je sadržavala ricin, što bi, ako bi bilo uspješno, bio prvi njemački biološki napad. Njemačke inteligentne službe Bundesnachrichtendienst (BND) dobile su dojavu britanske obavještajne službe da je državljanin Tunisa koji živi u Njemačkoj provodio sumnjive aktivnosti na internetskoj mreži. Ta je aktivnost uključivala kupnju mlina za kavu i 1000 ricinusovih zrna, ključnog sastojka iz kojeg se dobiva ricin (The Local, 2019).

U 2011. sjeveroistočni Japan pogodio je snažan potres, a cunami koji je uslijedio usmrtio je gotovo 19000 ljudi te pokrenuo lanac događaja koji su doveli do trostrukog otapanja nuklearne elektrane Fukushima. Bila je to druga najveća nuklearna katastrofa ikad nakon Černobila - obje su klasificirane kao događaji razine 7 na Međunarodnoj ljestvici nuklearnih i radioloških događaja, a rezultirala je evakuacijom tisuća ljudi iz područja oko elektrane. Četiri godine nakon katastrofe, muškarac je dronom 
koja je sadržavala radioaktivni pijesak doletio s područja Fukušime u ured premijera u Tokiju. Iako je let dronovima bio čin prosvjeda zbog japanske nuklearne politike, to je bio pokazatelj kako industrijska nesreća može ponuditi mogućnosti teroristima koji žele dobiti CBRN materijale (Time, 2018).

\section{Zaključak}

Terorizam je globalna prijetnja stalno prisutna na području EU i šire, samo mijenjajući svoje oblike. S obzirom na ubrzan razvoj različitih vrsta i oblika terorizma i terorističkih aktivnosti, EU nastoji pružiti snažan pravni odgovor u borbi protiv terorizma. U tom smjeru ide i recentni pravni izvor u obliku Direktive koja proširuje definiciju terorističkih kaznenih djela i terorističkih aktivnosti, osobito stavljajući naglasak na putovanja u inozemstvo radi činjenja terorističkih kaznenih djela te pohađanje obuke za terorizam. U odnosu na Republiku Hrvatsku možemo kazati da je kaznenopravni sustav prilagođen toj Direktivi te inkriminira navedena ponašanja. S druge pak strane, premda Europa još uvijek nije na udaru bioloških terorističkih djelovanja, upravo je sada vrijeme da se skupe resursi i eksperti za razvijanje inovativnih, održivih i učinkovitih rješenja kako bi preduhitrili potencijalne prijetnje. Tako je radom analizirana i komunikacija Europske komisije koja će samo započeti novi put u zaštiti, spremnosti i odgovoru na kemijske, biološke, radiološke i nuklearne prijetnje. Akcijskim planom zasigurno će se povećati suradnja između država članica EU te iskoristiti sve prednosti koje suradnja država članica pruža krenuvši od financijskih pa do znanstvenih. Komunikacija i prijedlozi Europske komisije prema Vijeću Europske unije i Europskom parlamentu definitivno predstavljaju korak naprijed u borbi protiv terorizma, međunarodnih prijetnji te bioloških ugroza.

\section{Literatura}

Bilandžić, Mirko. 2014. Sjeme zla: uvod u studije terorizma. Zagreb: Despot Infinitus. Cvjetković, Branko. 2002. Terorizam - sredstva i posljedice. Split: Laus.

Direktiva (EU) 2016/681 Europskog parlamenta i Vijeća o uporabi podataka iz evidencije podataka o putnicima (PNR) u svrhu sprečavanja, otkrivanja, istrage i kaznenog progona kaznenih djela terorizma i teških kaznenih djela, SL L 119.

Direktiva (EU) 2016/681 Europskog parlamenta i Vijeća od 27. travnja 2016. o uporabi podataka iz evidencije podataka o putnicima (PNR) u svrhu sprečavanja, otkrivanja, istrage i kaznenog progona kaznenih djela terorizma i teških kaznenih djela, SL 119/132.

Direktiva (EU) 2017/541 Europskog parlamenta i Vijeća o borbi protiv terorizma i zamjeni Okvirne odluke Vijeća 2002/475/JHA i izmjeni Odluke Vijeća 2005/671/JHA.

Direktiva 2012/29/EU Europskog parlamenta i Vijeća o uspostavi minimalnih standarda za prava, potporu i zaštitu žrtava kaznenih djela te o zamjeni Okvirne odluke Vijeća 2001/220/PUP, SL L 315. 
Direktiva 2012/29/EU Europskog parlamenta i Vijeća od 25. listopada 2012. o uspostavi minimalnih standarda za prava, potporu i zaštitu žrtava kaznenih djela te o zamjeni Okvirne odluke Vijeća 2001/220/PUP od 15. ožujka 2001, SL L 315.

Direktiva 2013/40/EU Europskog parlamenta i Vijeća o napadima na informacijske sustave i o zamjeni Okvirne odluke Vijeća 2005/222/PUP, SL L 218.

Direktiva Vijeća 2004/80/EZ o naknadi žrtvama kaznenih djela, SL L 261.

European Commission. 2017. Communication from the commission to the European parliament, the Council, the European economic and social committee and the committee of the regions: Action Plan to enhance preparedness against chemical, biological, radiological and nuclear security risks. https://eur-lex.europa.eu/legal-content/EN/TXT/ $\mathrm{PDF} /$ ?uri=CELEX:52017DC0610\&from=en.

European Union External Action. 2016. A global strategy for the European Union's Foreign and Security policy. https://eeas.europa.eu/topics/eu-global-strategy/17304/globalstrategy-european-unions-foreign-and-security-policy_en.

Europol. 2017. Izvješće o stanju i trendovima u pogledu terorizma (TE SAT). www.europol. europa.eu/sites/default/files/documents/tesat2017.pdf.

Europol. 2020. Izvješće Europola o situaciji i trendu terorizma za 2020. https://www.europol. europa.eu/activities-services/main-reports/eu-terrorism-situation-and-trend-report.

France. 2018. Tunisian-German couple in court over 'ricin attack plot' (24). https://www. france24.com/en/20190607-tunisian-german-couple-court-over-ricin-attack-plot.

Furedi, Frank. 2009. Poziv na teror: rastuće carstvo nepoznatog. Zagreb: Ljevak.

Hoffman, Bruce. 2006. Inside Terrorism. New York: Columbia University Press.

Interpol. 2017. Procjena ISIL-ovih prijetnji kemijskim oružjem izvan Iraka i Sirije. https:// www.un.org/press/en/2017/sc13060.doc.htm.

Kazneni zakon. Narodne novine, 125/11, 144/12, 56/15, 61/15, 101/17, 118/18, 126/19.

Odluka Vijeća 2005/671/PUP o razmjeni informacija i suradnji u vezi s kaznenim djelima terorizma, SL L 253.

Odluka Vijeća 2008/615/PUP o produbljivanju prekogranične suradnje, posebno u suzbijanju terorizma i prekograničnog kriminala, SL L 210.

Okvirna odluka Vijeća 2002/475/PUP o suzbijanju terorizma, SL L 164.

Okvirna odluka Vijeća 2002/584/PUP o Europskom uhidbenom nalogu i postupcima predaje između država članica, SL L 190.

Okvirna odluka Vijeća 2006/960/PUP o pojednostavljenju razmjene informacija i obavještajnih podataka između tijela zaduženih za izvršavanje zakona u državama članicama Europske unije, SL L 386.

Prijedlog Direktive Europskog parlamenta i Vijeća o suzbijanju terorizma i zamjeni Okvirne odluke Vijeća 2002/475/PUP o suzbijanju terorizma, COM (2015) 625.

Primorac, Damir, Miletic, Nenad i Pilic, Marko. 2018. Safety and legal framework on preventing of use of the financial system for money laundering according to solutions of directive (EU) 2015/849. Economic and Social Development: Book of Proceedings, 67-78. 
Shemer, Joshua i Shoenfeld, Yehuda. 2007. Terorizam i medicina. Zagreb: Medicinska naklada.

The Guardian. 2018. Salisbury poisonings: police name two Russian suspects. https://www. theguardian.com/uk-news/2018/sep/05/salisbury-poisonings-police-name-and-chargetwo-suspects.

The Local. 2019. Cologne couple in court over 'biological bomb plot'. https://www.thelocal. de/20190607/tunisian-german-couple-in-court-over-ricin-attack-plot.

Time. 2018. Japan Acknowledges the First Radiation-Linked Death From the Fukushima Nuclear Disaster. https://time.com/5388178/japan-first-fukushima-radiation-death/.

United States Department of Justice. 2018. Allen Charged In Seven-Count Federal Indictment With Threat To Use A Biological Toxin As A Weapon, Department of Justice, U.S. Attorney's Office, District of Utah. https://www.justice.gov/usao-ut/pr/allen-chargedseven-count-federal-indictment-threat-use-biological-toxin-weapon.

Vijeće Europske unije. 2020. Borba EU-a protiv terorizma. https://eur-lex.europa.eu/search. html?qid=1412582464618\&OBSOLETE_LEGISUM=false\&type=named\&SUM_2_ CODED=2307\&SUM_1_CODED=23\&name=summary-eu-legislation:justice_ freedom_security\&page $=1$.

\section{European legal framework for combating terrorism and biosecurity threats Summary}

The fight against terrorism and all its manifestations is a global challenge that requires constant coordination of the legal and practical aspects of international and national bodies. The relevant legal framework allows for the harmonized action of a range of actors against this serious crime. That is why it is not surprising that the European Union is constantly striving to improve the legal system in order to combat terrorism. In the first part of the paper, the author gives an overview of the criminal law framework in the fight against terrorism, especially the changes that have taken place in the very definition of terrorism and the expansion of terrorist activities. The second part of the paper is dedicated to the activities of the European Union in combating a specific modality of terrorism, bioterrorism, in the direction of reducing access to hazards and hazardous materials, ensuring greater preparedness in response to possible biological security risks, strengthening internal and external ties with key regional and international partners. increase knowledge of potential risks. Finally, the author gives an overview of the practical implications of terrorism on the territory of the European Union from Europol's statistical indicators and the incidents regarding CBRN attacks.

Key words: european legal framework, combating terrorism, biosecurity risks, action plan. 